\section{Wittgenstein and Smythies}

SIR - Contrary to some comments ${ }^{1,2}$, my recent letter in Nature was not an attack on Wittgenstein: nor did I ever claim he was insane ${ }^{3}$ (a purely legal term). As a (very) minor poet myself ${ }^{4}, I$ do not feel it any insult to be called a (good) poet rather than a (poor) philosopher. Nor ought there to be any shame in being paranoid or schizophrenic. It may even be helpful, as in the case of Rousseau, who, "as every one knows, suffered a terrifying paranoid breakdown in $1767-8 " 5$. This may have made him sensitive to certain negative aspects of human relationships, important for sociology, that most people prefer to ignore.

The Times in a leading article hauled me over the coals for so demeaning a great man as to call him paranoid. It seems to me that this shows a lamentable intolerance toward psychiatrically ill people: their achievements in spite of their illness should be admired.

My criticism was of those philosophers who misunderstand Wittgenstein. On the continent of Europe, 'philosophy' tends to involve an emotional and poetic attempt to grasp the 'essence of Being' or some such - a far cry from the traditions of Locke, Berkeley and Hume and their followers. The clarity of the latter is vastly to be preferred to the obscurity of the former. Wittgenstein himself once said 'philosophy ought really to be written only as a poetic composition.' So he wrote in aphorisms, as did Nietzsche, another greater as a poet than as a philosopher.

\section{Physics lesson}

SIR - John Maddox (Nature 354, 263; 1991) missed the real lesson of the current state of physics. Attempts to attack the "grand questions" have led to such dead ends as Einstein's unified field theory, strings, the philosophy of quantum measurement and quantum cosmology. On the other hand, study of such apparently messy and prosaic problems as the thermodynamics of fluids near their critical points has yielded deep insights into the nature of the physical world. The lesson is that science is led by experiment, and that the proper job of theorists is to predict and explain the results of experiments. The research that strikes the editor as narrow at the least increases our understanding of the natural world in a small way, and may some day have greater implications.

Washington University,

Campus Box 1105 ,

One Brookings Drive,

St Louis, Missouri 63130-4899, USA
As R. D. Laing has rightly claimed, schizophrenia and art can be closely intertwined (see, for example, the poet and artist Thomas Hennell's moving account of his own schizophrenic episode $^{6}$ ). Thus one can read Wittgenstein or Nietzsche as poetry with benefit. But one cannot base a study of mind or perception on either. Anyone who thinks that Wittgenstein was a great, or even a good, philosopher should read Jenny Teichman's Philosophy and the Mind (chapter 4 and especially pages 50-51)

It is strange that many philosophers still believe that important problems relating to mind and perception can be solved by 'linguistic' or 'logical' analysis (also known as 'folk psychology') rather than by slogging it out with observation, hypothesis and experiment. It is amazing, for example, that so many philosophers still adhere to the pre-scientific theory - totally at variance with modern cognitive neuroscience - known as naive or direct (phenomenal) realism ${ }^{7}$.

Institute of Neurology,

J. R. SMYTHIES

National Hospital,

Queen Square,

London WC1N 3BG, UK

1. Bird, R.J. Nature 351, 10 (1991)

Rakitis, E.T. Nature 351, 179 (1991)

Fischer, R., Kufferle, B \& Berner, P. Nature 353, 598 (1991).

4. Smythies, J.R. 'The Departed.' Poetry Rev. 43, 214 (1952)

5ent, N.J.H. Rousseau, 6-7 (Blackwell, Oxford, 1988)

6. Thomas Hennell, The Witness (Peter Davies, London, 1938).

Gregory, R.L. Mind in Science (Penguin, Harmondsworth, 1981)

\section{Misunderstanding}

SIR - I was surprised to read Cesare Emiliani talking about miracles, God and the Devil in response to my letter about the Turin Shroud dating (Nature 352, 187 and 353, 598; 1991). I think I have been misunderstood. My purpose was not to "lament" anything but to ask this simple question: is there something inaccurate in the description of the Shroud samples provided in the report of Damon et al. (Nature 337, 611-615; 1989)? One of the co-authors, Dr W. Woelfli, says "yes". If Woelfli is right, the error should be acknowledged in an authors' correction. Like many people, I believe that a careful description of the material and methods in a scientific report is a profitable approach. This is not a matter of God or Devil.

Pierre Busson

Lineberger Comprehensive

Cancer Center.

University of North Carolina,

Campus Box No. 7295,

Chapel Hill, North Carolina 27599, USA

\section{ODSQ}

SIR - In the belief that science might be better served by collections of quotations, we are compiling the Oxford Dictionary of Scientific Quotations to be published by Oxford University Press. We would welcome contributions, whether instructive, amusing, characteristic of a certain individual, crucial in formulating scientific principles, or whatever. Quotations may be from scientists both living and dead, and from other writers upon science. They may also be 'attrib.' or part of the 'folklore' of science. We would be especially grateful for slightly more out-of-the-way instances (perhaps quotations not yet famous but that deserve to become so).

\section{W. F. BYNUM ROY PORTER (Editors)}

ODSQ.

Wellcome Institute

for the History of Medicine,

183 Euston Road,

London NW1 2BN, UK

\section{Maxwell's role}

SIR - Your leading article about $\mathrm{Mr}$ Robert Maxwell (Nature 354, 93; 1991) is less than fair to his achievements. First, you say that "many [of Pergamon's] journals are undistinguished", while acknowledging that "some" have excellent reputations. In fact, in almost every field of science, at least one Pergamon journal is among the world leaders; for example, Neuroscience (founded 1976) is rated 17th in terms of impact factor out of all the 4,300 journals in every field of science in the Institute of Scientific Information database.

Neuroscience illustrates another feature of Maxwell's scientific publishing: he published the journal but gave the ownership to the International Brain Research Organization (of which I am director of publications) most of whose income now comes from the journal. Many scientific societies have benefited from arrangements of this kind with Pergamon Press.

I was also sorry to see you quoting the Board of Trade report, without mentioning that a few years later several of the criticisms in that report were withdrawn by the Board of Trade as unfounded in fact.

Scientists throughout the world owe a debt of gratitude to Maxwell for his vision and for his long-standing support of their different disciplines. In all my dealings with him he was absolutely correct and always kept his word.

A. DAVID SMITH

University Department of Pharmacology, Mansfield Road,

Oxford OX1 3QT, UK 